\title{
Secondary Metabolites from Thraustochytrium aureum and Their Biological Activity
}

\author{
Huu Giap Tran $\oplus^{1}$, Mai Thao Vu $\oplus^{1}$, Thi Tu Oanh Nguyen $\oplus^{1}$, \\ Thi Thoa Ha $\oplus^{1}$, Dang Diem Hong $\oplus^{2}$, Thi Hoai Thu Ngo $\oplus^{2}$, \\ Thi Thom Le $\oplus^{2}$, Cam Ha Nguyen $\oplus^{2}$ and Thi Minh Hang Nguyen $\oplus^{1,3^{*}}$
}

\author{
${ }^{1}$ Institute of Marine Biochemistry, Vietnam Academy of Science and Technology, 18 Hoang Quoc Viet, \\ Cau Giay, Ha Noi, Vietnam \\ ${ }^{2}$ Institute of Biotechnology, Vietnam Academy of Science and Technology, 18 Hoang Quoc Viet, \\ Giay, Ha Noi, Vietnam \\ ${ }^{3}$ Graduate University of Science and Technology, Vietnam Academy of Science and Technology, 18 Hoang \\ Quoc Viet, Cau Giay, Ha Noi, Vietnam
}

(Received October 15, 2021; Revised December 01, 2021; Accepted December 02, 2021)

\begin{abstract}
Phytochemical investigation of Thraustochytrium aureum led to the isolation of eleven compounds including ergosterol (1), 7-dehydroporiferasterol (2), (22E,24R)-ethylcholesta-7,22-dien-3 $\beta, 5 \alpha, 6 \beta$-triol (3), poriferasterol glucoside (4), perlolyrine (5), pyrrolezanthine-6-methyl ether (6), 3-(3-aminopropyl)-6-[(4-hydroxyphenyl)methyl]-2,5piperazinedione (7), 5-methyluracil (8), $1 H$-indole-3-carboxylic acid (9), adenosine (10), and $p$-hydroxybenzoic acid (11). Screening for $\alpha$-glucosidase inhibitory, antimicrobial and cytotoxic activities of the extracts and isolated compounds were carried out. The $n$-hexane extract was the most active, which showed strong $\alpha$-glucosidase inhibitory activity with $\mathrm{IC}_{50}$ of $48.22 \mu \mathrm{g} / \mathrm{mL}$, inhibition against $E$. faecalis, S. aureus and C. albicans microorganism strains with MIC values of 128, 64 and $64 \mu \mathrm{g} / \mathrm{mL}$, respectively. Compound 6 have shown to be the most active among isolated compounds, which inhibited $\alpha$-glucosidase with $\mathrm{IC}_{50}$ value of $7.96 \mu \mathrm{g} / \mathrm{mL} ;$ E. faecalis and C. albicans microorganism strains with MIC values of 64 and $16 \mu \mathrm{g} / \mathrm{mL}$ and inhibited the growth of A549, HepG2, MCF7 and LNCaP cancer cell lines with $\mathrm{IC}_{50}$ values of $62.26,41.03,57.21$ and $43.23 \mu \mathrm{g} / \mathrm{mL}$, respectively.
\end{abstract}

Keywords: Thraustochytrium aureum; alkaloid; steroid; microalga, $\alpha$-glucosidase. ㅇ 2021 ACG Publications. All rights reserved.

\section{Microalgal Source}

The heterotrophic microalga Thraustochytrium aureum Goldstein 1963 (BT6 strain) used in this study, was isolated from the mangrove forest at Mui Ne, Phan Thiet city, Binh Thuan province, Vietnam (latitude $10^{\circ} 56^{\prime} 00^{\prime \prime} \mathrm{N}$, longitude $108^{\circ} 17^{\prime} 00^{\prime \prime} \mathrm{E}$ ) in 2010, which was deposited at Department of Algal Biotechnology, Institute of Biotechnology belonging to Vietnam Academy of Science and Technology, Vietnam.

\section{Previous Studies}

Microalgae have been known as the largest and most diverse group of photosynthetic organisms in freshwater and marine systems. This group are promising sources for the sustainable production of many bioactive compounds including fatty acids, phycobiliproteins, chlorophylls, carotenoids, and vitamins, which

*Corresponding author: E-mail: minhhang@imbc.vast.vn Phone: +84 243-791-7053 Fax: +84 243-791-7054 


\section{Secondary metabolites from Thraustochytrium aureum}

are widely used in pharmaceuticals, cosmetics, and food additives. The natural bioactive compounds from microalgae attract interests of many researchers due to their potential therapeutic activities such as antioxidant, antiviral, antibacterial, antifungal, anti-inflammatory, antitumor, and antimalarial effects. Surprisingly, natural products from microalgae are almost unexplored compared to those isolated from terrestrial plants although microalgae have many advantages over plants. For instance, microalgae can grow rapidly, are easier to cultivate, and do not compete directly with crops for agricultural land. These advantages highlight the importance of developing microalgae for the production of medicinally important natural products as well as for pharmaceuticals discovery and development, among other bio products [1].

Thraustochytrium aureum is one of thraustochytrids, which have potential on commercial value due to their ability to produce a large amount of lipids, especially DHA, and their heterotrophic nature, which is suitable for fermentation technology [2-3]. T. aureum produced DHA in a level about 50\% of total lipids. All previous researches on $T$. aureum have focused on the biomass production, total lipids and DHA content [47]. Hitherto, there is no report in the secondary metabolites and biological activity of this species.

\section{Present Study}

In continuation of our research on bioactive compounds from Vietnamese marine microalgae, we focus our attention to heterotrophic microalga Thraustochytrium aureum because of biological activities of its extracts. Preliminary screening for the $\alpha$-glucosidase inhibitory, antimicrobial and cytotoxic activities of $n$-hexane, EtOAc and aqueous extracts from T. aureum were carried out. $n$-hexane extract showed a good $\alpha$ glucosidase inhibitory potential with $\mathrm{IC}_{50}$ value of $48.22 \mu \mathrm{g} / \mathrm{mL}\left(\mathrm{IC}_{50}\right.$ value of acarbose is $164.08 \mu \mathrm{g} / \mathrm{mL}$ ) and inhibited E. faecalis, S. aureus and C. albicans strain with MIC values of 128,32 and $256 \mu \mathrm{g} / \mathrm{mL}$, respectively. The EtOAc extract exbibited moderate inhibition of E. faecalis and $C$. albicans with MIC values of 256, 128 and $128,64 \mu \mathrm{g} / \mathrm{mL}$, respectively while aqueous extract show no biological activities. No extract showed significant cytotoxicity againts any of A549, HepG2, MCF7 and LNCaP cancer cell lines. The $n$-hexane and EtOAc extracts which contain potentially bioactive compounds were further investigated for their phytochemical constituents.

Microalgal Culture: Thraustochytrium aureum (BT6 strain) was kept on GPY medium (glucose $0.2 \%$, polypeptide $0.1 \%$, yeast extract $0.05 \%$, agar $1.5 \%, 17.5 \mathrm{~g} / \mathrm{L}$ artificial sea water (ASW). The primary seed culture was carried out by taking colonies of BT6 strain culture in a petri dish in $1000 \mathrm{~mL}$ Erlenmeyer flask with $350 \mathrm{~mL}$ Bajpai liquid medium which contained $10 \mathrm{~g} / \mathrm{L}$ glucose, $2.5 \mathrm{~g} / \mathrm{L}$ yeast extract, and $0.5 \% \mathrm{NaCl}$ content.

The primary seed culture flasks were incubated for $96 \mathrm{~h}$ at $28^{\circ} \mathrm{C}$ with shaking at $200 \mathrm{rpm}$. Fermentation was carried out using a $30 \mathrm{~L}$ fermentor, and a Bajpai medium that contained $5 \%$ glucose, $1 \%$ yeast extract, and $0.5 \% \mathrm{NaCl}$. The inoculum size was $3 \%$ of the total liquid volume in fermentor. Temperature was kept at $32^{\circ} \mathrm{C}-37^{\circ} \mathrm{C}$. Dissolved oxygen was maintained above $10 \%$ by manually increasing the stirring speed from $250 \mathrm{rpm}$ to a maximum of $450 \mathrm{rpm}$. The aeration rate was always 0.5 volume air/(vol. medium)/min after filtering through a $0.2 \mathrm{~mm}$ filter. Instead of antifoam, $50 \mathrm{~mL}$ of vegetable oil with the trade name Neptune ${ }^{\circledR}$ Gold (made by Cai Lan Vegetable Oil Limited Company, Ha Long City, Quang Ninh Province) was added to the $30 \mathrm{~L}$ fermentor. BT6 strain biomass was harvested after $120 \mathrm{~h}$ of fermentation. Under adverse culture conditions in terms of nutrient medium (5\% glucose, $1 \%$ industrial yeast and $0.5 \%$ salinity) and room temperature (from $32^{\circ} \mathrm{C}-37^{\circ} \mathrm{C}$ ) in $30 \mathrm{~L}$ fermentor (handmade), the growth of T. aureum BT6 species accounted the maximum after $120 \mathrm{~h}$ of culture with dry biomass, lipid and DHA contents reaching $6.98 \pm 0.04 \mathrm{~g} / \mathrm{L} ; 5.5 \pm 0.13 \%$ of dry biomass and $0.14 \pm 0.01 \%$ of total fatty acids, respectively.

Algal biomass was harvested by centrifugation at 4,000 rpm for $10 \mathrm{~min}$. The algae paste was washed three times with sterile distilled water and then dried to a constant weight in a drying oven at $50^{\circ} \mathrm{C}$ and stored in desiccators.

Extraction and Isolation: The dried microalga $(5.0 \mathrm{~kg})$ was grinded and extracted with $n$-hexane, followed by $\mathrm{MeOH}$ to give the respective crude extracts after solvent's evaporation under reduced pressure. The crude methanolic extract was further partitioned between EtOAc and water to get EtOAc $(48.0 \mathrm{~g})$ and aqueous $(70.0 \mathrm{~g})$ extracts after removing of total solvent in vacuo.

The $n$-hexane extract $(120 \mathrm{~g})$ was subjected on a silica gel CC, eluted with a system gradient of $n$ hexane/Me ${ }_{2} \mathrm{CO}(100: 0,90: 10,80: 20,70: 30,60: 40,50: 50,30: 70,0: 100, \mathrm{v} / \mathrm{v})$ to yield ten fractions $(\mathrm{H} 1-\mathrm{H} 10)$. 
The fraction $\mathrm{H} 2$ was further chromatographed on a silica gel CC, eluted with the mixture of $n$-hexane/ $\mathrm{Me}_{2} \mathrm{CO}(90: 10, \mathrm{v} / \mathrm{v})$ to get five subfractions $(\mathrm{H} 2.1-\mathrm{H} 2.6)$. The subfraction $\mathrm{H} 2.5$ was purified on a reverse phase silica gel (RP-18) CC with $\mathrm{Me}_{2} \mathrm{CO} / \mathrm{H}_{2} \mathrm{O}(80: 20$, v/v) as eluent to obtain compounds 1 (5.1 mg) and 2 $(4.9 \mathrm{mg})$. Compound $3(5.2 \mathrm{mg})$ was isolated from fraction $\mathrm{H} 7$ by a silica gel $\mathrm{CC}$ with $n$-hexane/ $\mathrm{Me}_{2} \mathrm{CO}$ $(80: 20, \mathrm{v} / \mathrm{v})$ as eluent, followed by a RP-18 silica gel $\mathrm{CC}$, eluted with a mixture of $\mathrm{MeOH} / \mathrm{Me}{ }_{2} \mathrm{CO} / \mathrm{H}_{2} \mathrm{O}$ $(100: 1: 1, \mathrm{v} / \mathrm{v} / \mathrm{v})$. Compound $4(20.5 \mathrm{mg})$ was isolated from fraction $\mathrm{H} 9$ by a silica gel CC eluting with $n$ hexane/ $\mathrm{Me}_{2} \mathrm{CO}$ (70:30), followed by RP-18 silica gel CC with $\mathrm{MeOH} / \mathrm{H}_{2} \mathrm{O}(90: 10$, v/v) as eluent. The EtOAc extract $(47.0 \mathrm{~g})$ after repeated column chromatography on silica gel, using $\mathrm{CH}_{2} \mathrm{Cl}_{2} / \mathrm{EtOAc}$ and $\mathrm{CH}_{2} \mathrm{Cl}_{2} / \mathrm{MeOH}$ as eluents, or over Sephadex LH-20, eluting with $\mathrm{MeOH} / \mathrm{CH}_{2} \mathrm{Cl}_{2}(90: 10$, v/v) and $\mathrm{MeOH}$, yielded compounds 5 (4.0 mg), 6 (3.5 mg), 7 (2.5 mg), 8 (9.0 mg), 9 (3.3 mg), 10 (21.0 mg), 11 (5.5 mg).

$\alpha$-Glucosidase Inhibitory Assay: The $\alpha$-glucosidase inhibitory assay was carried out according to the previous method [8]. Sample was dissolved in DMSO (400 $\mathrm{mg} / \mathrm{mL})$ and phosphate buffer to final concentrations of $256.0,128.0,32.0,8.0$, and $2.0 \mathrm{mg} / \mathrm{mL}$. In a $96-$ well plate, a reaction mixture containing sample, phosphate buffer $(100 \mathrm{mM}, \mathrm{pH} 6.8), \alpha$-glucosidase $(0.4 \mathrm{U} / \mathrm{mL})$ were preincubated at $37{ }^{\circ} \mathrm{C}$ for 10 min. Then, $20 \mu \mathrm{L} p$-nitrophenyl $\alpha$-D-glucopyranoside (pNPG) $(2.5 \mathrm{mM})$ was added as a substrate and incubated further at $37{ }^{\circ} \mathrm{C}$ for $30 \mathrm{~min}$. The reaction was stopped by adding $25 \mu \mathrm{L} \mathrm{Na}_{2} \mathrm{CO}_{3}(0.2 \mathrm{M})$. The rate of $p$-nitrophenol released from pNPG was measured at $410 \mathrm{~nm}$ with Elisa reader. Without test sample was set up in parallel as a control. All experiments were performed in triplicate and acarbose was used as a positive control. The results were expressed as percentage inhibition, which was calculated using the formula,

$$
\text { Inhibitory activity }(\%)=\left(\mathrm{A}_{\mathrm{c}}-\mathrm{As}\right) \times \mathrm{A}_{\mathrm{c}} \times 100
$$

Where, As is the absorbance in the presence of tested sample and Ac is the absorbance of control.

The $\mathrm{IC}_{50}$ value is defined as the concentration of inhibitor to inhibit $50 \%$ of its activity under the assayed conditions, which was determined graphically from inhibition curves (log inhibitor concentration vs percent of inhibition).

Antimicrobial Activity Assays: Antimicrobial assays were carried out using Enterococcus faecalis (ATCC13124), Staphylococcus aureus (ATCC25923), Bacillus cereus (ATCC13245), Escherichia coli (ATCC25922), Pseudomonas aeruginosa (ATCC27853), Salmonella enterica (ATCC12228) and Candida albicans (ATCC1023). Stock solutions of samples were prepared in DMSO, and the antimicrobial assays were carried out in 96-well microtiter plates against the microbial strains $\left(5 \times 10^{5} \mathrm{CFU} / \mathrm{mL}\right)$ using a modification of the published method [9]. After incubation for $24 \mathrm{~h}$ at $37^{\circ} \mathrm{C}$, the absorbance at $650 \mathrm{~nm}$ was measured using a microplate reader. Streptomycin and cyclohexamide were used as reference compounds.

Cytotoxic Activity Assay: The cancer cell lines were maintained in Dulbecco's D-MEM medium, supplemented with $10 \%$ fetal calf serum, L-glutamine $(2 \mathrm{mM})$, penicillin $\mathrm{G}(100 \mathrm{UI} / \mathrm{mL})$, streptomycin $(100$ $\mu \mathrm{g} / \mathrm{mL})$ and gentamicin $(10 \mu \mathrm{g} / \mathrm{mL})$. Stock solutions of compounds were prepared in $\mathrm{DMSO} / \mathrm{H}_{2} \mathrm{O}(1 / 9)$, and cytotoxicity assays were carried out in 96-well microtiter plates against A549 (ATCC, CCL-185 TM), HePG2 (ATCC, HB-8065 ${ }^{\mathrm{TM}}$ ), MCF7 (ATCC, HTB-22 ${ }^{\mathrm{TM}}$ ), and LNCaP (ATCC, CRL-1740 ${ }^{\mathrm{TM}}$ ) cancer cell lines $(3 \mathrm{x}$ $10^{3}$ cells $/ \mathrm{mL}$ ) using a modification of the published method [10]. After $72 \mathrm{~h}$ incubation at $37{ }^{\circ} \mathrm{C}$ in air/ $\mathrm{CO}_{2}$ (95:5) with or without test compounds, cell growth was estimated by colorimetric measurement of stained living cells by neutral red. Optical density was determined at $540 \mathrm{~nm}$ with a Titertek Multiscan photometer. The $\mathrm{IC}_{50}$ value was defined as the concentration of sample necessary to inhibit the cell growth to $50 \%$ of the control. Ellipticine was used as a reference compound.

Phytochemical Studies of the Extracts: From $n$-hexane anf EtOAc extracts, eleven compounds were isolated. The isolated compounds were identified as $(24 E, 24 R)$-methylcholesta-5,7,22-trien-3 $\beta$-ol (ergosterol) (1) [11], (22E,24R)-ethylcholesta-5,7,22-trien-3 $\beta$-ol (7-dehydroporiferasterol) (2) [11], (22E,24R)-ethylcholesta7,22-dien-3 $\beta, 5 \alpha, 6 \beta$-triol (3) [12], (22E,24R)-ethylcholesta-5,22-dien-3-O- $\beta$-D-glucopyranoside (poriferasterol glucoside) (4) [13], perlolyrine (5) [14], pyrrolezanthine-6-methyl ether (6) [15], 3-(3aminopropyl)-6-[(4-hydroxyphenyl)methyl]-2,5-piperazinedione (7) [16], 5-methyluracil (8) [17], $1 \mathrm{H}$-indole-3carboxylic acid (9) [18], adenosine (10) [19] and $p$-hydroxybenzoic acid (11) [20] by comparing their NMR data (Supporting information) to those reported in the literatures. 
Secondary metabolites from Thraustochytrium aureum

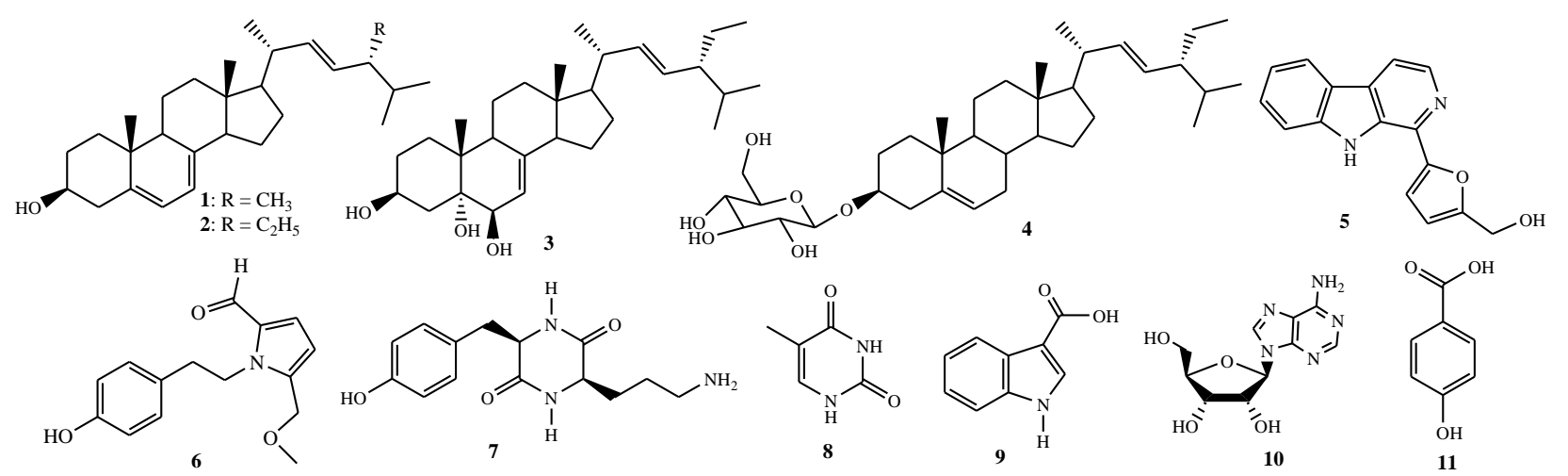

Figure 1. Chemical structure of the compounds (1-11)

Biological Activites of Isolated Compounds: In the present study, inhibitory activity test of the $\alpha$-glucosidase of compounds 1-8 were performed in vitro using spectrophotometric methods. Compounds $\mathbf{5}$ and $\mathbf{6}$ were shown to be more potent $\alpha$-glucosidase inhibitors with IC $_{50}$ values of $26.86 \pm 0.29$ and $7.96 \pm 0.75 \mu \mathrm{g} / \mathrm{mL}$, compared with the control acarbose $\left(\mathrm{IC}_{50} 164.08 \pm 2.89 \mu \mathrm{g} / \mathrm{mL}\right.$ ). Compound 7 exhibited weak activity with $\mathrm{IC}_{50}$ value of $234.4 \pm 3.39 \mu \mathrm{g} / \mathrm{mL}$. The $\alpha$-glucosidase inhibitory activity of $p$-hydroxybenzoic acid (11) and $\beta$ adenosine (10) with $\mathrm{IC}_{50}$ of $56.4 \mu \mathrm{M}$ and $9.3 \mathrm{mM}$ were previously reported [21,22]. The nitrogen containing moiety in compound $\mathbf{5}$ and $\mathbf{6}$ may increase their binding affinity with target enzyme and result in lower $\mathrm{IC}_{50}$ values with higher therapeutic efficiency [23]. Additionally, pyrroles (6) and their derivatives (5) could act as glycosidase inhibitors, and thus can mimic oxocarbocation intermediate structure, enable tight binding and strongly inhibit the enzyme [24].

Table 1. $\alpha$-glucosidase inhibitory activity of compounds 1-8

\begin{tabular}{cccc}
\hline Compounds & $\mathbf{I C}_{\mathbf{5 0}}(\boldsymbol{\mu} \mathbf{g} / \mathbf{m L})$ & Compounds & IC $\mathbf{5 0}(\boldsymbol{\mu g} / \mathbf{m L})$ \\
\hline $\mathbf{1}$ & $>256$ & $\mathbf{5}$ & $26.86 \pm 0.29$ \\
$\mathbf{2}$ & $>256$ & $\mathbf{6}$ & $7.96 \pm 0.75$ \\
$\mathbf{3}$ & $>256$ & $\mathbf{7}$ & $234.4 \pm 3.39$ \\
$\mathbf{4}$ & $>256$ & $\mathbf{8}$ & $>256$ \\
Acarbose & $164.08 \pm 2.89$ & & \\
\hline
\end{tabular}

In the antimicrobial assay, six compounds 1, 4 and 6-9 were examined against seven microbial strains. All compounds 1, 4 and 6-9 showed strong inhibition with MIC values of 16, 64, 64, 16, 64, $64 \mu \mathrm{g} / \mathrm{mL}$ on $E$. faecalis strain, and $128,32,16,16,16,16 \mu \mathrm{g} / \mathrm{mL}$ on $C$. albicans yeast, respectively. Only compound 1 exhibited inhibition on $S$. aureus with MIC value of $64 \mu \mathrm{g} / \mathrm{mL}$.

In the cytotoxic assay, only compound $\mathbf{6}$ showed the moderate cytotoxic activity against all of four tested cancer cell lines $\mathrm{A} 549$, HepG2, MCF7, $\mathrm{LNCaP}$ with $\mathrm{IC}_{50}$ values of $62.26,41.03,57.21$ and 43.23 $\mu \mathrm{g} / \mathrm{mL}$, respectively.

Table 2. Antimicrobial activity of compounds 1, 4, 6-9

\begin{tabular}{|c|c|c|c|c|c|c|c|}
\hline \multirow{3}{*}{ Sample } & \multicolumn{7}{|c|}{$\operatorname{MIC}_{50}(\mu \mathrm{g} / \mathrm{mL})$} \\
\hline & \multicolumn{3}{|c|}{ Gram (+) } & \multicolumn{3}{|c|}{ Gram (-) } & \multirow{2}{*}{$\begin{array}{c}\text { Yeast } \\
\text { C. albicans }\end{array}$} \\
\hline & E. faecalis & $\begin{array}{c}S . \\
\text { aureus }\end{array}$ & $\begin{array}{c}B . \\
\text { cereus }\end{array}$ & E. coli & P. aeruginosa & S. enterica & \\
\hline 1 & 16 & 64 & $>256$ & $>256$ & $>256$ & $>256$ & 128 \\
\hline 4 & 64 & $>256$ & $>256$ & $>256$ & $>256$ & $>256$ & 32 \\
\hline 6 & 64 & $>256$ & $>256$ & $>256$ & $>256$ & $>256$ & 16 \\
\hline 7 & 16 & $>256$ & $>256$ & $>256$ & $>256$ & $>256$ & 16 \\
\hline 8 & 64 & $>256$ & $>256$ & $>256$ & $>256$ & $>256$ & 16 \\
\hline 9 & 64 & $>256$ & $>256$ & $>256$ & $>256$ & $>256$ & 16 \\
\hline Streptomycin & 256 & 256 & 128 & 32 & 256 & 128 & \\
\hline Cyclohexamide & & & & & & & 32 \\
\hline
\end{tabular}


Tran et al., Rec. Nat. Prod. (2022) 16:5 493-498

Table 3. Cytotoxic activities of compounds 4 and 6-9

\begin{tabular}{ccccc}
\hline \multirow{2}{*}{ Compound } & \multicolumn{4}{c}{ IC $_{\mathbf{5 0}}(\boldsymbol{\mu} \mathbf{g} / \mathbf{m L})$} \\
\cline { 2 - 5 } & $\mathbf{A 5 4 9}$ & HepG2 & MCF7 & LNCaP \\
\hline $\mathbf{4}$ & $>100$ & $>100$ & $>100$ & $>100$ \\
$\mathbf{6}$ & $62.26 \pm 3.51$ & $41.03 \pm 3.05$ & $57.21 \pm 1.50$ & $43.23 \pm 2.08$ \\
$\mathbf{7}$ & $>100$ & $>100$ & $>100$ & $>100$ \\
$\mathbf{8}$ & $>100$ & $>100$ & $>100$ & $>100$ \\
$\mathbf{9}$ & $>100$ & $>100$ & $>100$ & $>100$ \\
Ellipticine & $\mathbf{0 . 4 1} \pm \mathbf{0 . 0 4}$ & $\mathbf{0 . 3 3} \pm \mathbf{0 . 0 3}$ & $\mathbf{0 . 4 1} \pm \mathbf{0 . 0 5}$ & $\mathbf{0 . 3 6} \pm \mathbf{0 . 0 4}$ \\
\hline
\end{tabular}

Alkaloids are commonly found in terrestrial plants, but rarely in marine algae [25]. Surprisingly, pyrrole alkaloids such as $\mathbf{5}$ and $\mathbf{6}$ with significant $\alpha$-glucosidase inhibitory activity and antimicrobial activity could be isolated from T. aureum. Among isolated compounds, $\mathbf{6}$ is the most active compound with broad spectrum of biological activities. So that, this compound could be a highly potential candidate for further study on pharmaceutical applications. Notably, only small quantities of compounds could be isolated in this study, which limit the number of biological test and the biological mechanism. The similar study with large scale of dry mass of this microalga in order to isolate other bioactive substances with low content have been currently carried out in laboratory.

\section{Acknowledgments}

This work is financially supported by Vietnam Academy of Science and Technology (Code: TĐDLB0.06/20-22).

\section{Supporting Information}

Supporting Information accompanies this paper on http://www.acgpubs.org/journal/records-ofnatural-products

\section{ORCID}

Tran Huu Giap: 0000-0002-3899-5328

Vu Mai Thao: 0000-0001-8010-7171

Nguyen Thi Tu Oanh: 0000-0001-8179-3011

Ha Thi Thoa: 0000-0003-2711-1440

Dang Diem Hong: 0000-0001-8762-3929

Ngo Thi Hoai Thu: 0000-0003-2163-6262

Le Thi Thom: 0000-0002-2889-6828

Nguyen Cam Ha: 0000-0002-3463-1607

Nguyen Thi Minh Hang: 0000-0002-2826-0483

\section{References}

[1] W. Fu, D.R. Nelson, Z. Yi, M. Xu, B. Khraiwesh, K. Jijakli, A. Chaiboonchoe, A. Alzahmi, D. AlKhairy, S. Brynjolfsson and K. Salehi-Ashtiani (2017). Chapter 6 Bioactive compounds from microalgae: Current development and prospects, Studies Nat. Prod. Chem. 54, 199-225.

[2] K. Kalidasan, K.S. Sunil, K. Kayalvizhi and K. Kathiresan (2015). Polyunsaturated fatty acidproducing marine thraustochytrids: A potential source for antimicrobials. J. Coast. Life Med. 3, 848851.

[3] K. Kalidasan, K.S. Sunil, R. Narendran and K. Kathiresan (2015). Antioxidant activity of mangrovederived marine thraustochytrids, Mycosphere 6, 602-611.

[4] V. Ugalde, R.E. Armenta, K.-P. Azadeh; Z. Sun, K.T. Berryman and M.S. Brooks (2018). Improvement of culture conditions for cell biomass and fatty acid production by marine thraustochytrid F24-2, J. Appl. Phycol.. 30, 329-339. 


\section{Secondary metabolites from Thraustochytrium aureum}

[5] K.H. Min, H.H. Lee, P. Anbu, B.P. Chaulagain and B.K. Hur (2012). The effects of culture condition on the growth property and docosahexaenoic acid production from Thraustochytrium aureum ATCC 34304, Korean J. Chem. Eng. 29, 1211-1215.

[6] E. Julianti, M. Fathurohman, S. Damayanti and R. E. Kartasasmita (2018). Isolated of heterotrophic microalgae Thraustochytrium aureum as a potential source for docosahexaenoic acid (DHA), Mar. Res. Indonesia. 43, 79-86.

[7] Y. Taoka, N. Nagano, Y. Okita, H. Izumida, S. Sugimoto and M. Hayashi (2011). Effect of Tween 80 on the growth, lipid accumulation and fatty acid composition of Thraustochytrium aureum ATCC 34304, J. Biosci. Bioeng. 111, 420-424.

[8] N.T. Tra, N.V. Tuyen, P.V. Cuong, N.T.T. Ha, L.T. Tu Anh and N.T. Son (2021). Chemical constituents from the leaves of Styrax argentifolius H.L.Li and their biological activities, Phytochem Lett. 41, 70 -73.

[9] F. Hadacek and H. Greger (2000). Testing of antifungal natural products: methodologies, comparability of results and assay choice, Phytochem. Anal. 11, 137-147.

[10] J.P. Hughes, S. Rees, S.B. Kalindjian and K.L. Philpott (2011). Principles of early drug discovery, Br. J. Pharmacol. 162, 1239-1249.

[11] F. Matteo, T. Pasquale and L. Rafael (2010). Phytosterol from Dunaliella tertiolecta and Dunaliella salina: A potentially novel industrial application, Bioresour. Technol. 101, 4144-4150.

[12] M. Anna, P. Vincenzo and S. Donato (1989), New polyhydroxysterols from the dictyoceratid sponges Hippospongia communis, Spongia officinalis, Ircinia variabilis, and Spongionella gracilis, J. Nat. Prod. 52(5), 952-961.

[13] K. Mahbuba, B. Mirajum and M. A. Quader (2012), Sterols and sterol glucoside from Phyllanthus species, Dhaka Univ. J. Sci. 60(1), 5-10.

[14] B. Dassonneville, B. Witulski and H. Detert (2011). [2+2+2] Cycloadditions of Alkynylynamides - A Total synthesis of perlolyrine and the first total synthesis of "Isoperlolyrine", Eur. J. Org. Chem. 2011, 2836-2844.

[15] G-H. Xu, Y-H. Kim, S-J. Choo, I-J. Ryoo, J-K. Yoo1, J-S. Ahn, and I-D. Yoo (2009). Chemical constituents from the leaves of Ilex paraguariensis inhibit human neutrophil elastase, Arch. Pharm. Res. 32, 1215-1220.

[16] Y. Sasaki, Y. Akutsu, K. Suzuki, S. Sakurada, and K. Kisara (1981). Structure and analgesic activity relationship of Cyclo-Tyrosyl-Arginyl and its three stereoisomers, Chem. Pharm. Bull. 29(11), 34033406.

[17] Z.-G. Ding, J.-Y. Zhao, P.-W. Yang, M.-G. Li, R. Huang, X.-L. Cui and M.-L. Wen (2009). ${ }^{1}$ H and ${ }^{13} \mathrm{C}$ NMR assignments of eight nitrogen containing compounds from Nocardia alba sp.nov (YIM 30243T), Magn. Reson. Chem. 47, 366-370.

[18] M.S. Morales-Rios, J. Espiieira and P. Joseph-Nathan (1987). ${ }^{13} \mathrm{C}$ NMR spectroscopy of indole derivatives, Magn. Reson.Chem. 25, 377-395.

[19] P. Ciuffreda, S. Casati and A. Manzocchi (2007). Spectral assignments ang reference data complete ${ }^{1} \mathrm{H}$ and ${ }^{13} \mathrm{C}$ NMR spectral assignment of $\alpha$ - and $\beta$-adenosine, 2 -deoxyadenosine and their acetate derivatives, Magn. Reson. Chem. 45, 781-784.

[20] T. Jianwen, B. Pawe, L. Jikai, S. Bernd, S. Ales and H. Klaus (2004). Universally occurring phenylpropanoid and species-specific indolic metabolites in infected and uninfected Arabidopsis thaliana roots and leaves, Phytochemistry 65, 691-699.

[21] S.-H. Lam, J.-M. Chen, C.-J. Kang, C.-H. Chen and S.-S. Lee (2008). $\alpha$-Glucosidase inhibitors from the seeds of Syagrus romanzoffiana, Phytochemistry 69, 1173-1178.

[22] S.W. Jung, A.J. Han, H.J. Hong, M.G. Choung, K.S. Kim and S.H. Park (2006). $\alpha$-Glucosidase inhibitors from the roots of Codonnopsis lanceolata Trauv., Agric. Chem. Biotechnol. 49(4), 162-164.

[23] J. Zhen, Y. Dai, T. Villani, D. Giurleo, J. E. Simon and Q. Wu (2017). Synthesis of novel flavonoid alkaloids as a-glucosidase inhibitors, Bioorg. Med. Chem. 25, 5355-5364.

[24] J.F. Witte and R.W. McClard (1991). Synthesis of a potent $\alpha$-glucosidase inhibitor epimeric to fr 900483. Tetrahedron Lett. 32, 3927-3930.

[25] K.C. Güven, A. Percot and E. Sezik (2010). Alkaloids in Marine Algae, Mar. Drugs 8, 269-284.

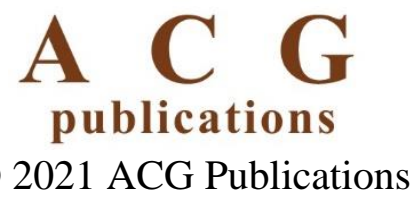

